\title{
اللغة العربية كونها لغة الدين الإسلامي واللغة العالمية
}

\author{
M. Rusydi Khalid \\ Universitas Islam Negeri Alauddin Makassar \\ Email: profrusydikhalid@gmail.com
}

\begin{abstract}
ملخص
إن اللغة العربية بعد نزول القرآن بها قد صارت لغة الدين وخاصةة لغة الإسلام لغة المسلمين في العالم أجمع ـ وهي اللغة التي

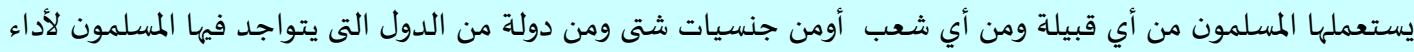

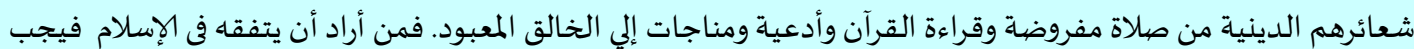
عليه أن يستوعب اللغة العربية الفصحى الصحيحة في كل علومها نحوها و صرفها وبلاغتها ومعانيها الدلالية وغيرها من علومها

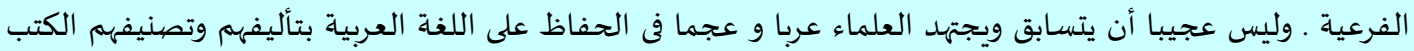

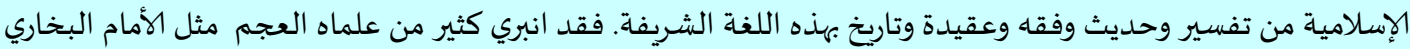

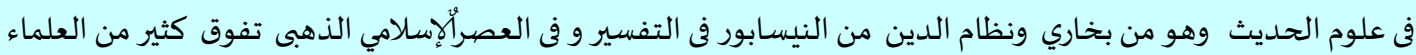

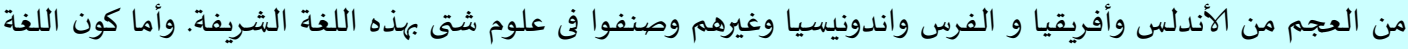

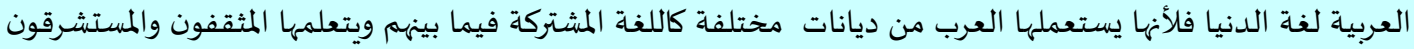

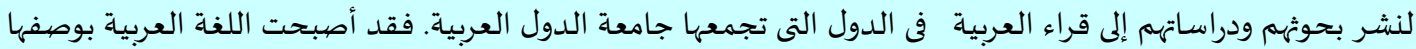

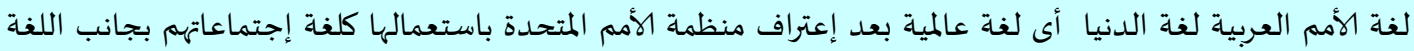

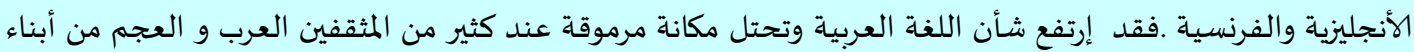

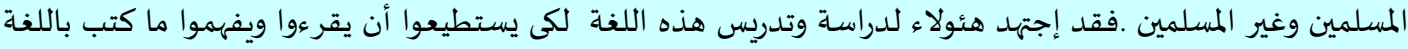

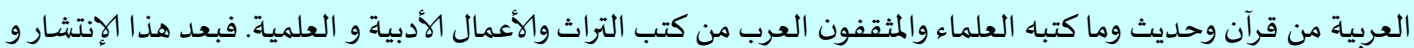
التوسع بدأ ظهور أفكار وآراء لتطوير اللغة العربية لمسايرة تطور العلم والتكنولوجيا وتكثير مفرداتها وحتى تيسير قواعدها الصعبة كما هى فى عصبر سيبويه.

الكلمات المفتاحية : لغة المسلمين , اللغة العالمية , المستشرقون
\end{abstract}

\section{Abstrak}

Bahasa Arab setelah turunnya Al Qur'an dalam bahasa ini berubah dari bahasa regional menjadi bahasa agama, bahasa umat Islam di seluruh dunia. Bahasa ini digunakan kaum muslimin apapun sukunya, bangsanya, negerinya untuk melafalkan bacaan shalat fardhu dan Sunnah, membaca Al Qur'an, dan berdoa serta munajat kepada Allah SWT. Siapa saja yang ingin mendalami ajaran Islam selayaknya menguasai bahasa Arab dengan berbagai aspeknya seperti nahwu, Sharaf, balaghah dan semantiknya. Para ulama baik Arab maupun non Arab berupaya keras menjaga kepasihan bahasa Arab dengan menyusun, mengarang kitab-kitab keislaman selain nahwu seperti tafsir, hadis, fikhi, akidah, dan sejarah dalam bahasa ini. Bahasa Arab kini sudah menjadi bahasa internasional yang dipelajari oleh banyak bangsa di dunia. Khususnya para orientalis barat untuk menyebarkan studi dan penelitian mereka kepada para pembaca Arab di negara-negara yang tergabung pada jami'at ad duwal Al 'arabiyah. Bahasa Arab sudah menjadi bahasa yang diakui PBB untuk digunakan dalam sidang-sidang internasional di samping bahasa Inggris, Perancis, dan China.

Kata kunci: Bahasa Arab; Al Our'an; Bahasa internasional; Orientalis 


\section{مقلدمة}

إن اللغة العربية بعد نزول القرآن بها قد صارت لغة الدين وخاصة لغة الإسلام لغة المسلمين في العالم أجمع. وهي اللغة التي يستعملها المسلمون من أي قبيلة ومن أي شعب أو من جنسيات شتى ومن دولة من الدول التى يتواجد فيها المسلمون لأداء شعائرهم الدينية من صالاة مفروضة وقراءة القرآن وأدعية ومناجات إلي الخالق المعبود. فمن أراد أن يتفقه في الإسلام فيجب عليه أن يستوعب اللغة العربية الفصحى الصحيحة في كل علومها نحوها و صرفها وبلاغتها ومعانيها الدلالية وغيرها من علومها الفرعية .وليس عجيبا أن يتسابق ويجتهد العلماء عربا و عجما في الحفاظ على اللغة العربية بتأليفهم وتصنيفهم الكتب الإسلامية من تفسير وحديث وفقه وعقيدة وتاريخ بهذه اللغة الشريفة. فقد انبري كثير من علماه العجم مثل الأمام البخاري فن علوم الحديث وهو من بخاري ونظام الدين من النيسابور فن التفسير و فن العصرألإسلامي الذهبى تفوق كثير من العلماء من العجم من الأندلس وأفريقيا و الفرس واندونيسيا وغيرهم وصنفوا في علوم شتى بهذه اللغة الشريفة.

وأماكون اللغة العربية لغة الدنيا فلأفها يستعملها العرب من ديانات مختلفة كاللغة المشتركة فيما بينهم ويتعلمها المثقفون والمستشرقون لنشر بحوثهم ودراساةم إلى قراء العربية في الدول التى بحمعها جامعة الدول العربية. فقد أصبحت اللغة العربية بوصفها لغة الأمم العبية لغة الدنيا أى لغة عالمية بعد إعتراف منظمة الأمم المتحدة باستعمالها كلغة إجتماعاتم بجانب اللغة الأنجليزية والفرنسية .فقد إرتفع شأن اللغة العربية وتحتل مكانة مرموقة عند كثير من المثقفين العرب و العجم من أبناء المسلمين وغير المسلمين . فقد إجتهد هئولاء لدراسة وتدريس هذه اللغة لكى يستطيعوا أن يقرءوا ويفهموا ما كتب باللغة العبية من قرآن وحديث وما كتبه العلماء والمثقفون العرب من كتب التراث والأعمال الأدبية و العلمية. فبعد هذا الإنتشار والتوسع بدأ ظهور أفكار وآراء لتطوير اللغة العربية لمسايرة تطور العلم والتكنولوجيا وتكثير مفرداتا وحتى تيسير قواعدها الصعبة كما هى في عصر سيبويه.

\section{ميزات العربية كلغة القرآن.}

لا ينكر أحد أن لغة القرآن عربية. وهى عربية فن نهوها و صرفها و صورها البلآغية لكنها عربية لا كالعربية , لأنها بلغت حد الإعجاز ولأن لها مميزات أدركها العلماء وصارت علما من علوم القرآن 
وحده. فمن تلك المميزات أو خصائص لغة القرآن ما يلى (عبد الغفور محمود مصطفى جعفر : $(50$ :

الإنتقاء. كل ألفاظ القرآن منتقاة وحروفها متآلفة وما يوصف بالغرابة منها فالمقصود أنه حسن مستغرب فن التأويل بحيث لا يتساوى في العلم به أهله وسائر الناس. فالقرآن إنتقى ألفاظه إنتقاء

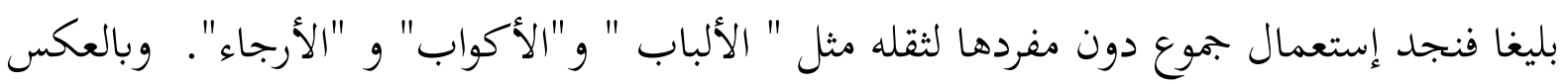

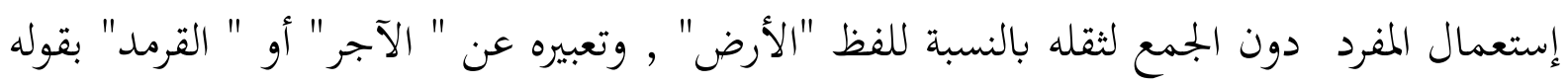

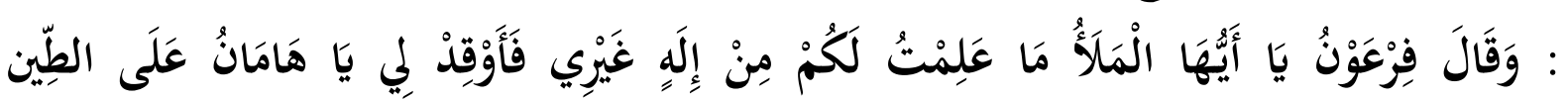
(القصص:38). فهذا ألطف كثيرا وأخف من ذينك اللفظين اللذين استعملهما الفصحاء ولم يعرفوا غيرهما. والإنتقاء ظاهر أيضا في إستخدام كلمات ووجوه من لغات مختلفة للعرب. وهذا الأمر ليس لسبب السياسة اللغوية التي بتمع العرب على مائدة واحدة أو ما إلى ذلك بل زاء إد وحوى من ألى أسرار

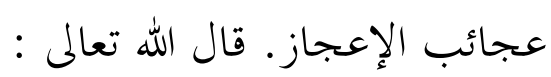

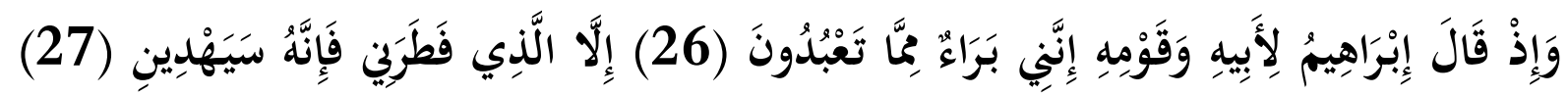

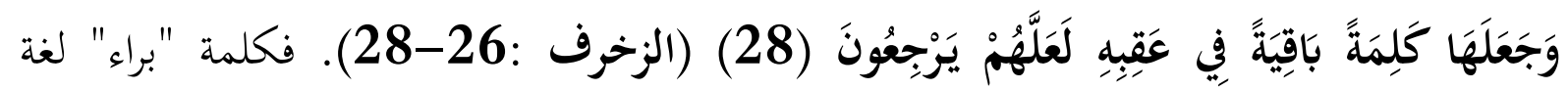

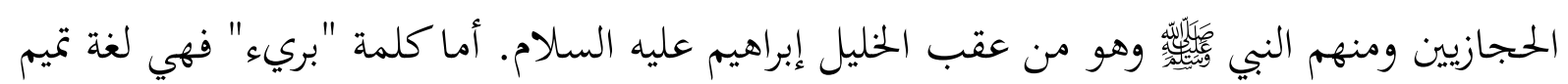

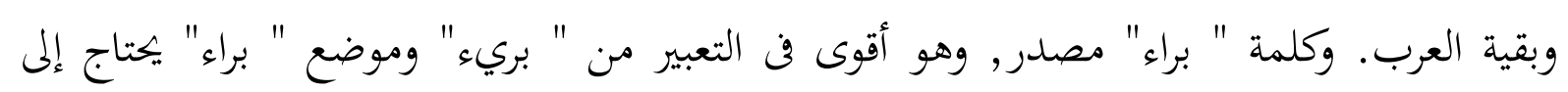
القوة لأن إبراهيم يواجه فيه بالخطاب أباه و قومه.

التناسب. ذلك الذي يظهر فن سلاسة الكلمات في تحاورها وتعاطفها بترتيب لا يبدو سره من أول وهلة. هذا التناسب مثلا نجده في الترتيب والمعنى في المحرمات من النساء في الآية القرآنية الآتية:

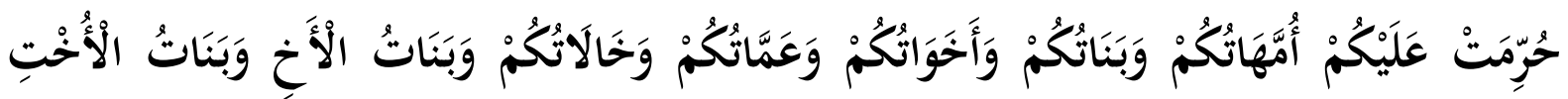

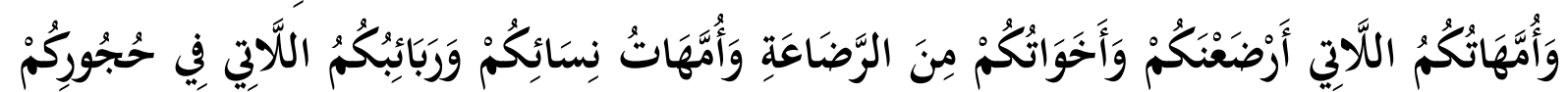

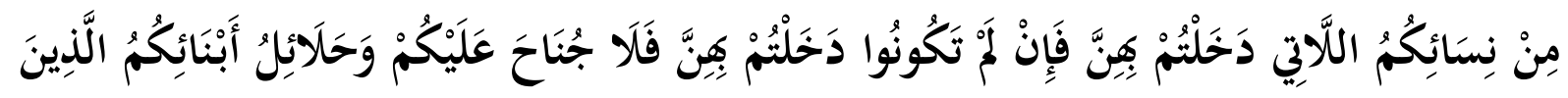




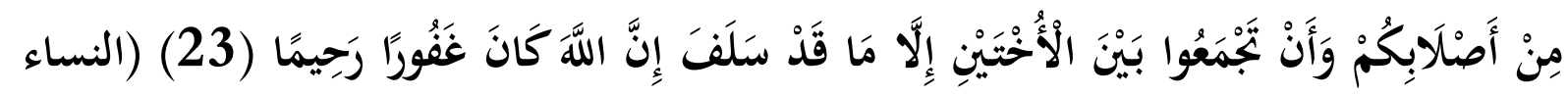

إن الآية تبدأ بذكر الأم لعظم حرمتها وإلالائها بنفسها ومكان بعضيتها , فهي أصل لكل من يدلى

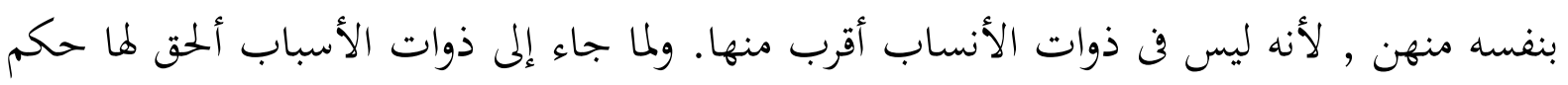

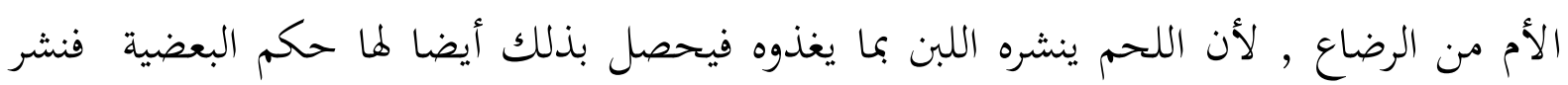

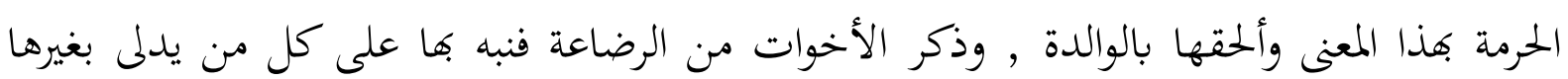

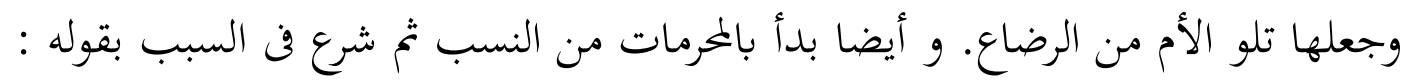

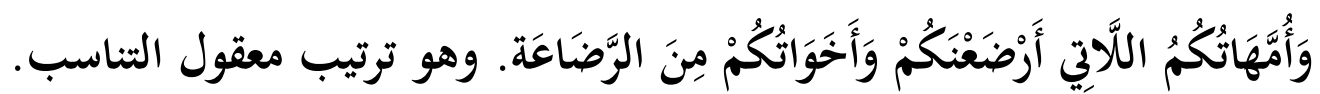

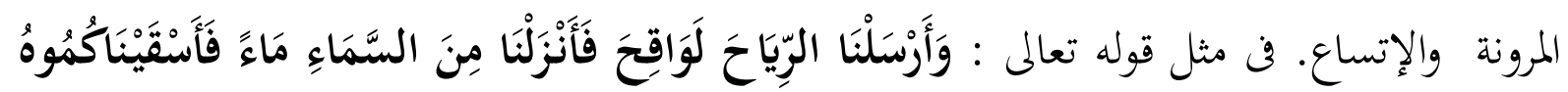

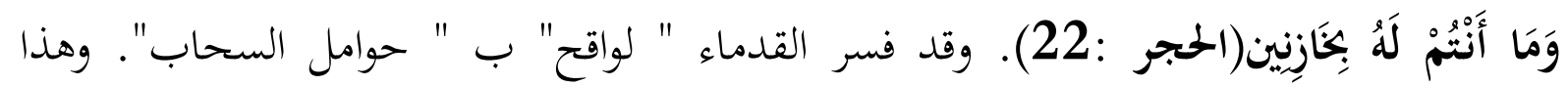

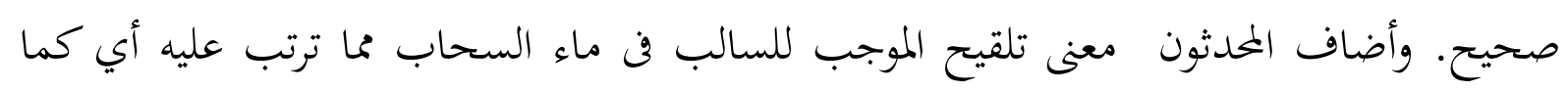

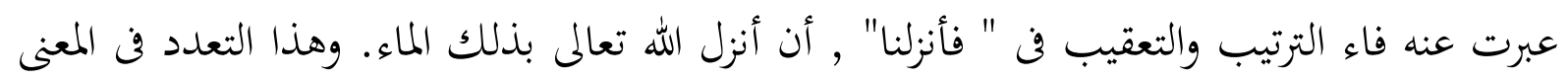

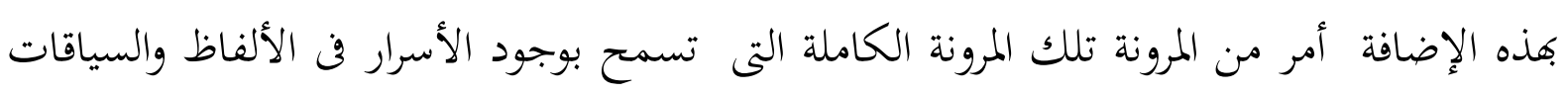
والتراكيب.

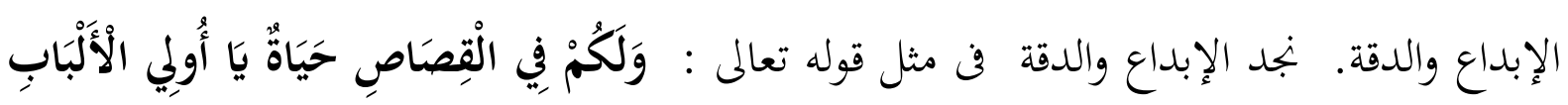

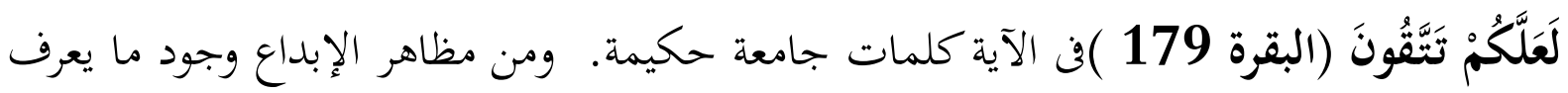

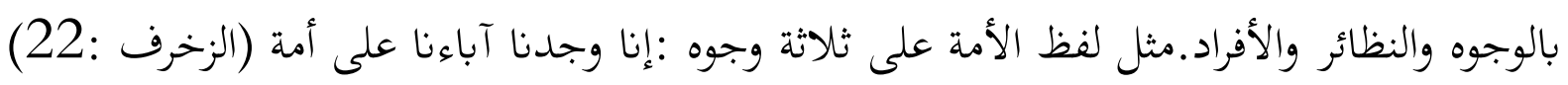

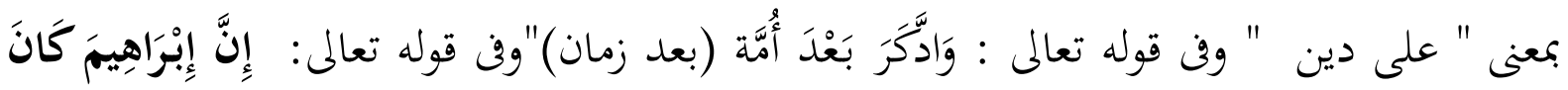

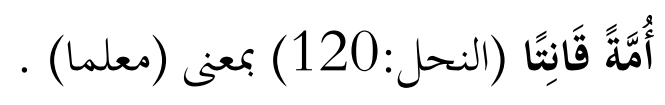

الجدة والإختراع. الأمثلة التي نستطيع أن نقدمها هي كأحرف التنبيه فن فواتح السور أو الحروف المقطعات مثل آلم , حّم , طّه . وقد تكلم فيها كثير من المفسرين وقالوا أن الله وحده أعلم بمرادها

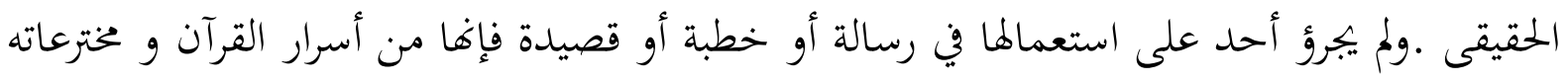


مما ترك للعلماء يجتهدون في تفسيره أو تأويله أو يتوقفون. فمنهم من يقول أله أعلم بمراده , ومنهم من يقول إها تنبيه على أن القرآن مؤلف من حروفكم وعجزتم عن معارضته فوجب أنس أن تؤمنوا بأنه

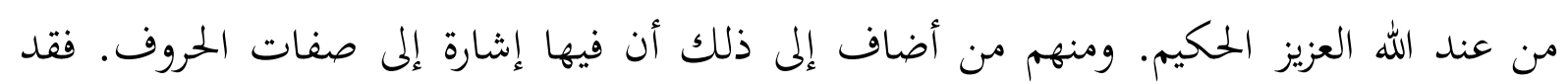

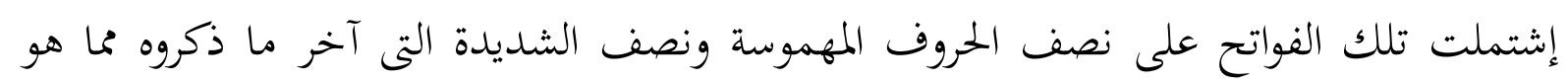

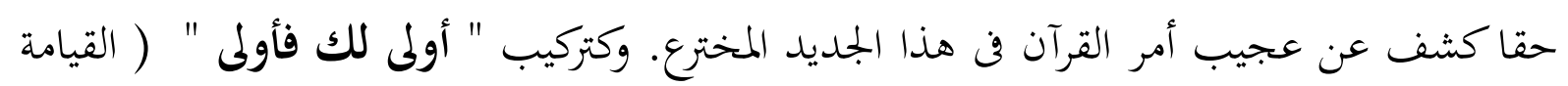

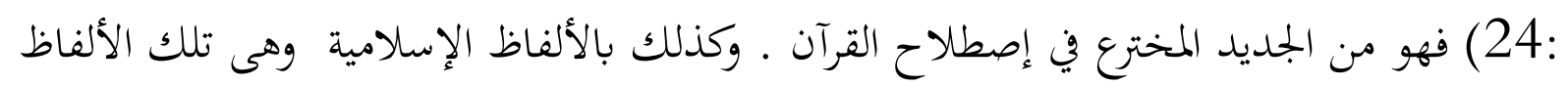

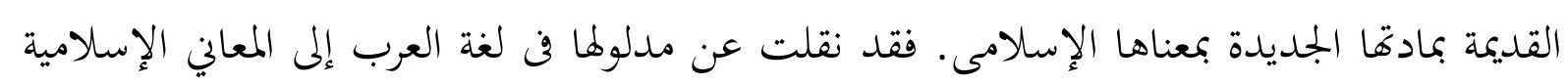

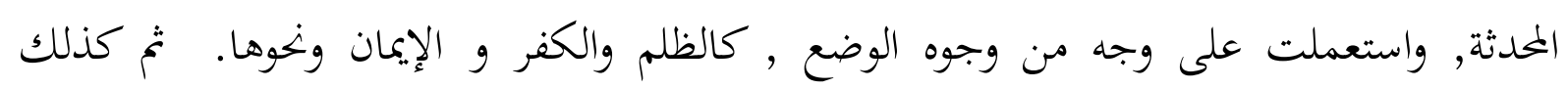

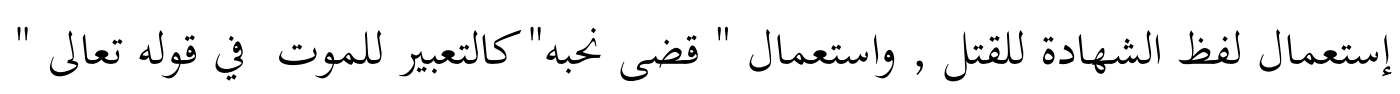

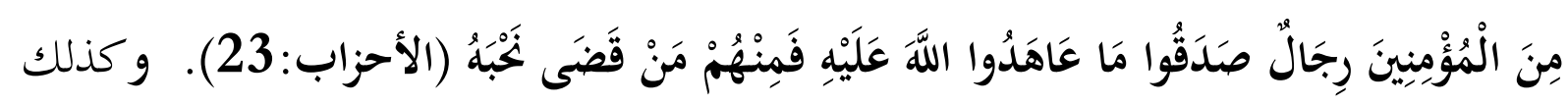
مثل إستعمال المشترك فن معنييه في قوله تعالى :

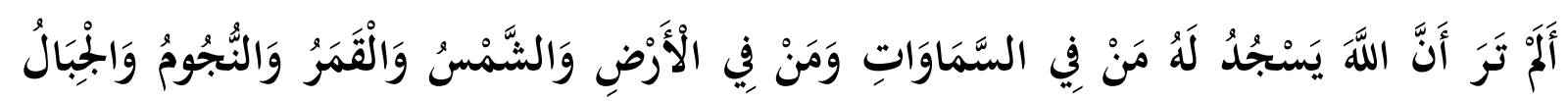

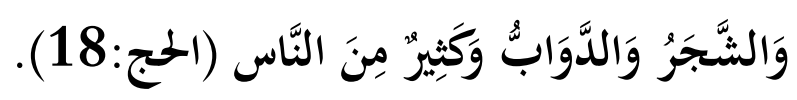

في هذه الآية لفظ " يسجد" يشير إلى المعنيين المعنى الأول هو السجود بالمعنى الشرعي وهو وضع المحئ

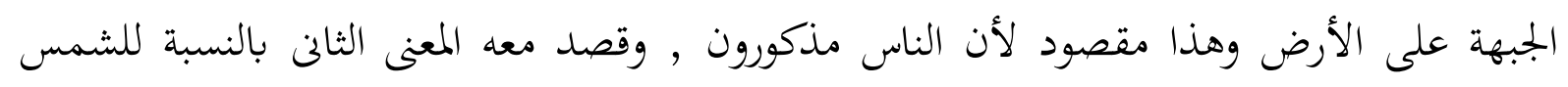
والقمر والنجوم والجبال والشجر ومانعها. وكذلك في قوله تعالى : و و ولجبال

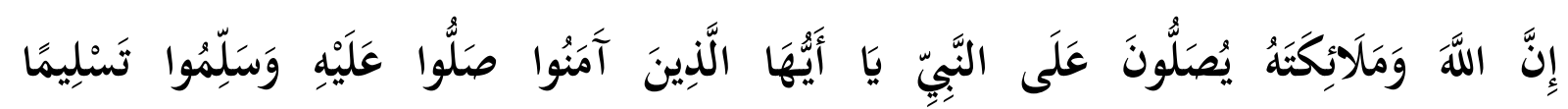
(56)(الأحزاب : (56). (56).

فالفعل ( يصلون) واحد في النص وقصد منه الصلاة بمعنى الرحمة من الله تعالى , والصلاة بمعنى الإستغفار من المالائكة. 
كوها ذات علوم شريفة منصوصة ومستنبطة.

وقد جعل الدهلوي في كتابه الفوز الكبير فن أصول التفسير كما ورد في التفسير و المفسرون (عبد الغفور محمود مصطفى جعفر:2007) العلوم المنصوصة فن القرآن خمسة :

الأول : علم الأحكام من الواجب والمندوب والمباح والمكروه والحرام , من قسم العبادات أو

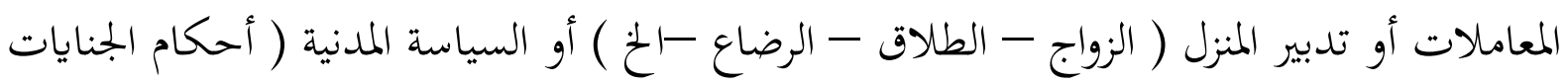
الخ). الثانى : علم المخاصمة والرد على الفرق الضالة الأربع من اليهود والنصارى والمشركين والمنافقين.

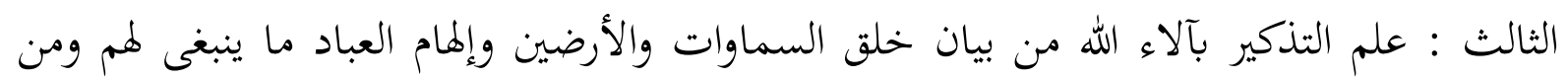
بيان كمالات الله سبحانه وتعالى. الرابع : علم التذكير بأيام الله يعنى بيان الوقائع التى أوجدها الله

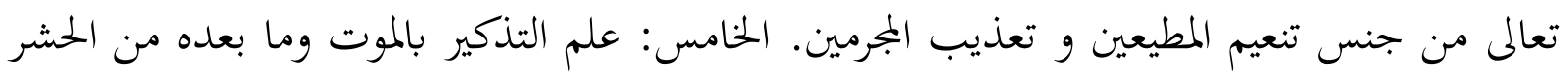
والنشر والحساب و الميزان والجنة والنار.

أما العلوم المستنبطة فستة أجناس :

الأول : العلوم المستنبطة بواسطة قواعد الإستباط الشرعية وقوة الملكة العلمية. فمنها أحكام الفقه

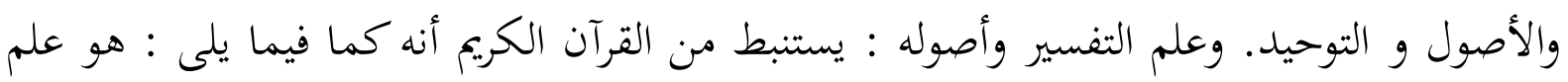

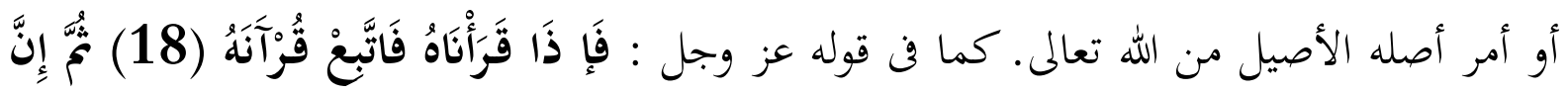

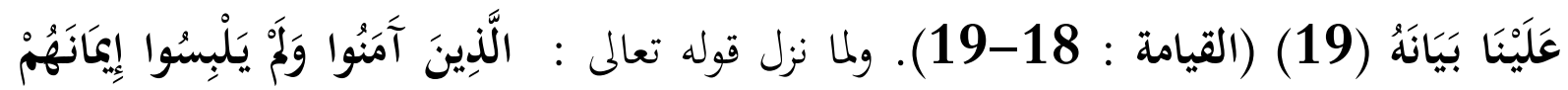

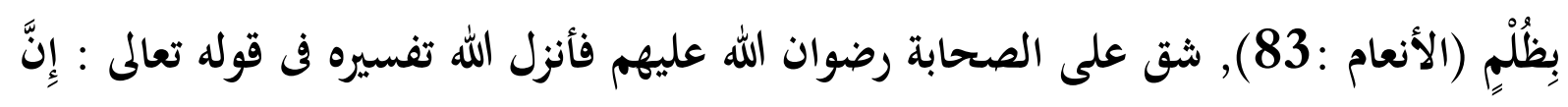

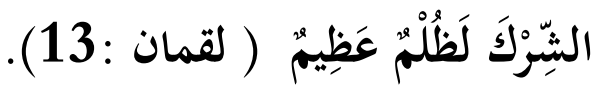

الثانى : العلوم المستنبطة بواسطة ملكة التمرس بما يسمى علوم الأوائل مثل الطب المعروف للأطباء

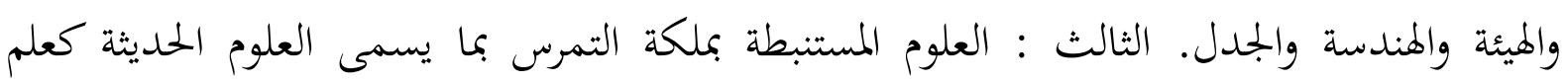

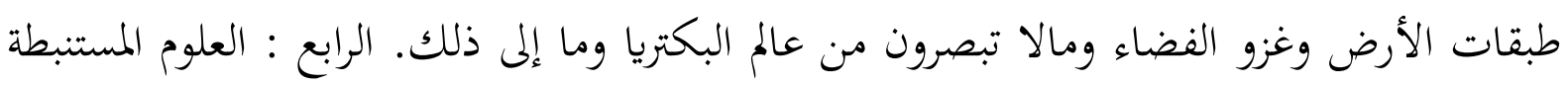
بواسطة قوة الملكة الأدبية مما يسمى بالمعانى الثانوة ومستتبعات التركيب. الخامس : العلم الناشئ عند إند 
القرآن من قوة البركة المودعة فيه الواصلة إلى الإنسان. السادس : العلم الناشئ من قوة الصفاء النفسي.

كوها معجزة. إن لغة القرآن ليست فقط فصيحة بليغة فن قمة البلاغة بل هي فوق ذلك كله

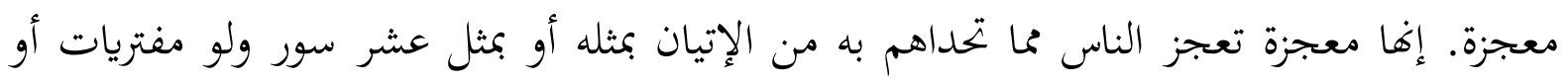

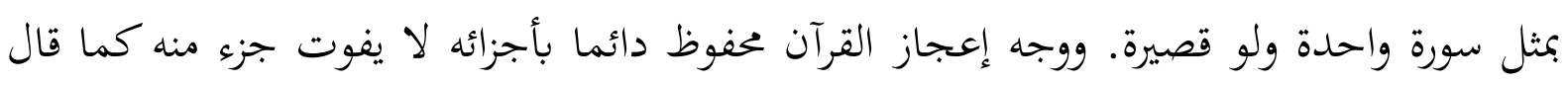

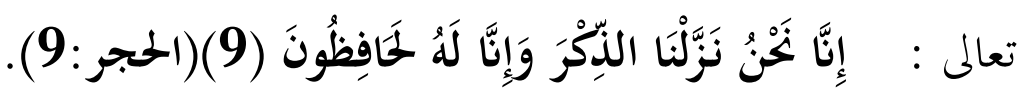
ومما يفسر لنا عن معجزة القرآن ويحقق فن نفوسنا معانى قرآنية هى هذه الأيات القرآنية : قُلْه لَئنِ

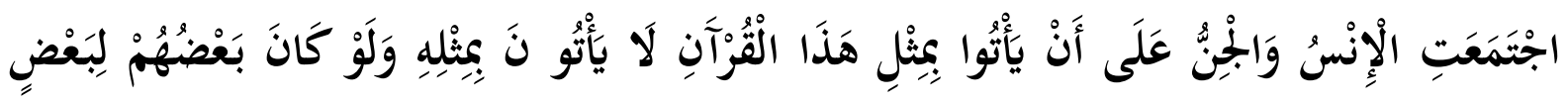

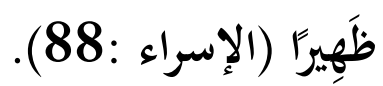

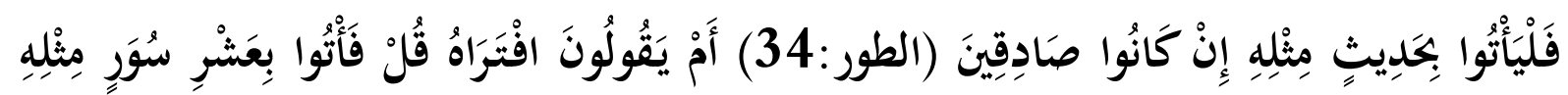

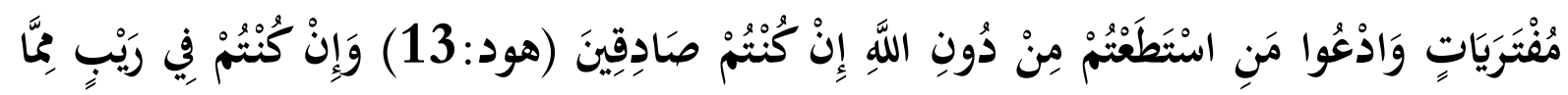

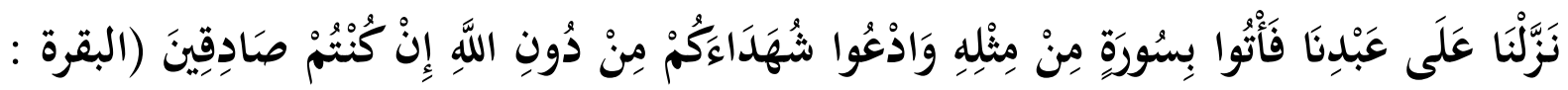

العوامل الدافعة إلى بقاء اللغة العربية إن هناك عوامل عدة أدت إلى تعلم وتعليم العربية وبقاءها عند العرب والمسلمين فن كل مكان بعان بعد العداء

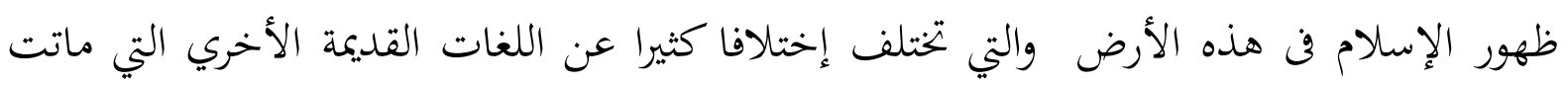

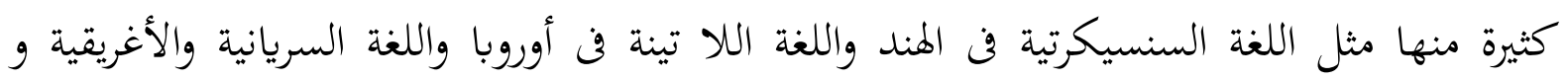
غيرها من اللغات وبقيت بعضها مع تغييرات كثيرة في قواعدها ومفرداتما ومعانيها وبعض أصوات

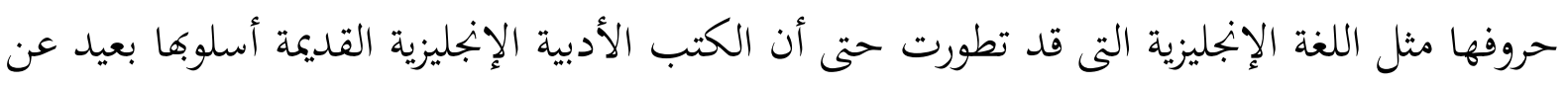

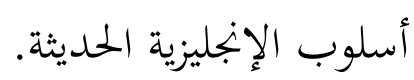

فمن تلك العوامل والأسباب في خلود العربية مايلى ( الفوزان :العربية بين يديك : المقدمة ص أ: ب 
إن اللغة العربية من الدين أو جزء من الدين الإسلامى. فقد رأي الإمام ابن تيمية رمهه الله أن تعلم

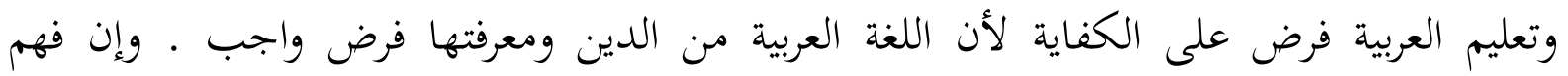

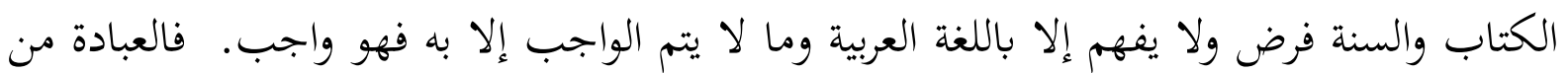

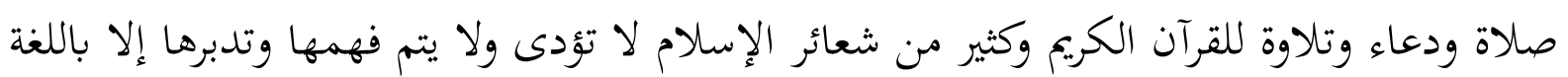

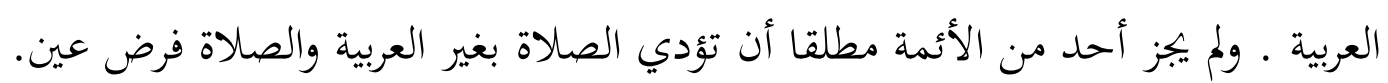

معرفتها تحمى من الوقوع فن الشبه والبدع. قال الإمام الشافعى رممه الله : ماجهل الناس ولا اختلفوا

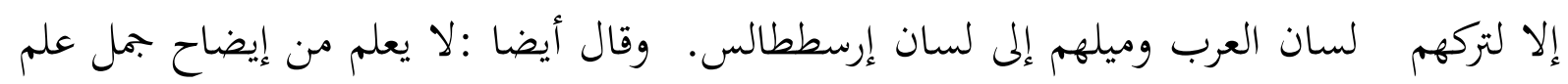

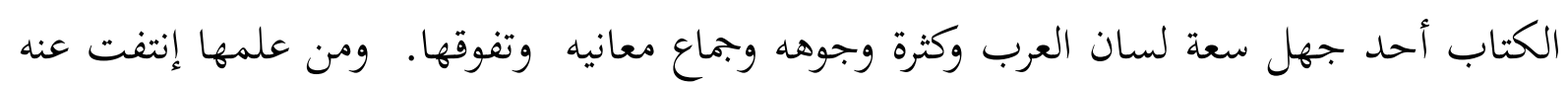

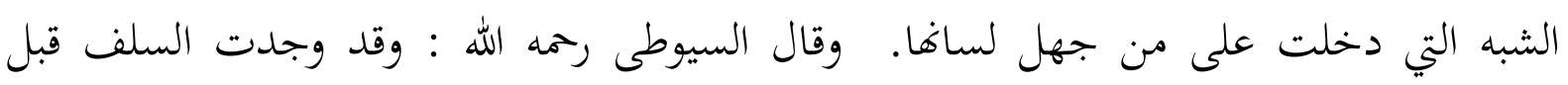

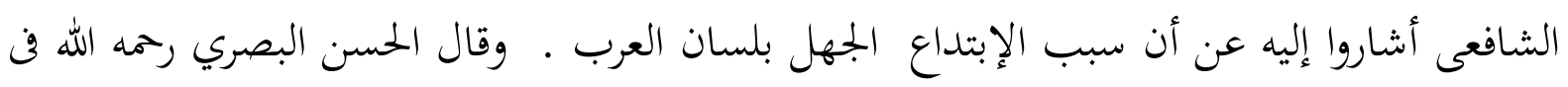

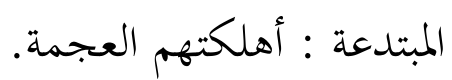

عرفة اللغة العربية سبب من أسباب التيسير كما قال تعلى : فإنما يسرناه بلسانك لعلهم يتذكرون (5ان كان

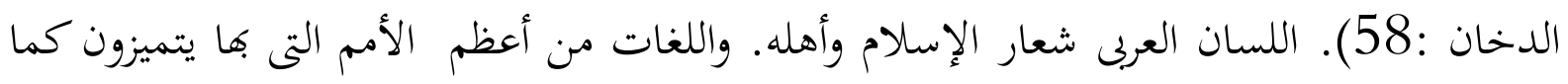

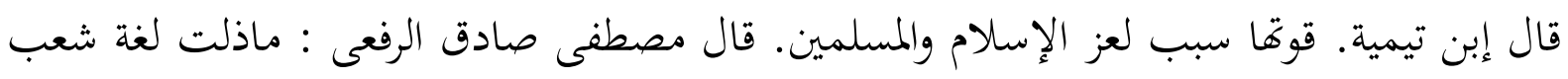

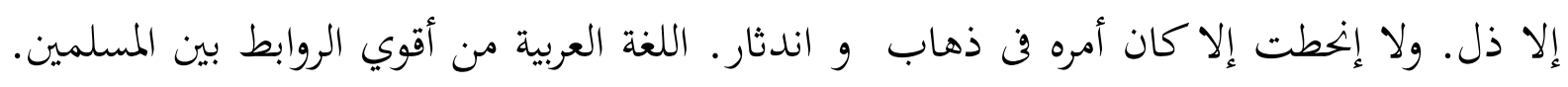

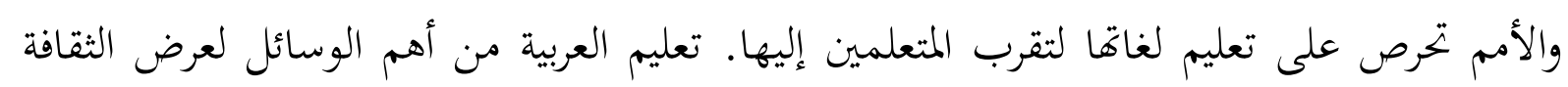

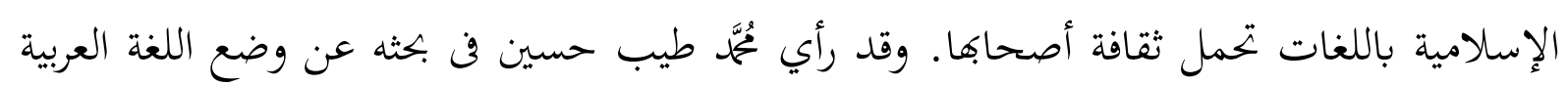

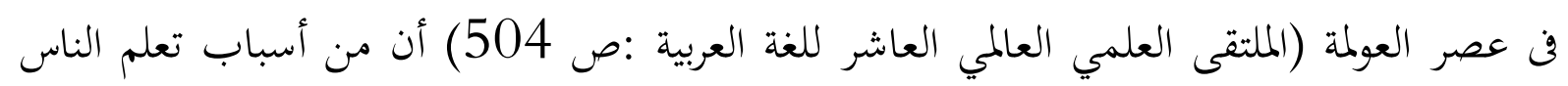

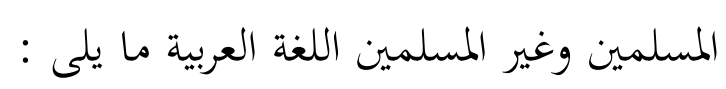
لأهما لغة الدين الإسلامي. من أجل التواصل المعريف والعلمي والثقافي. من أجل العمل فن البلا د العربية. من أجل السياحة

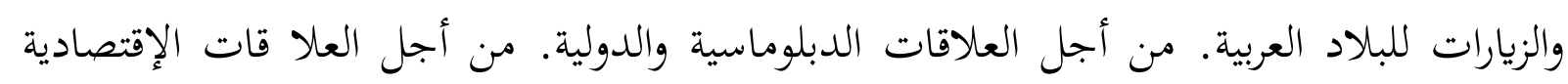
والتجارية. 
جاءت التحديات للغة العربية من الداخل ومن الخارج فمن الداخل جاءت من أبناء العرب أنفسهم الذين قد تأثروا بأفكار و نظريات لغوية غربية من المستشرقين واللغويين. فهم يرون أن لغة الإسلام الموجودة في القرآن والحديث هى اللغة القديمة فلهم أن يستعملوها في العبادات والشعائر الدينية فحسب ـ وأما في المحادثات اليومية فيستعملون لهجاهم العامية التى يصعب على المسلمين الأعاجم اللذين قد قضوا معظم حياهم في تعلم ودراسة العربية الفصحى بقواعدها النحوية و الصرفية لأن

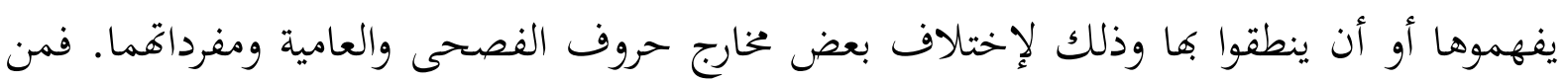
هذه الظاهرة اللغوية فقد قدم بعض المثقفين الذين تأثروا بأفكارعلمية غربية منها التشجيع لترويج واستعمال اللهجات العامية الدارجة في المحادثات اليومية بين أبناء العرب في المناطق المختلفة

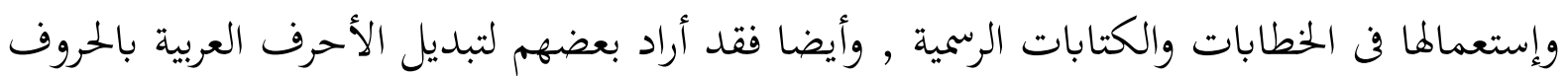

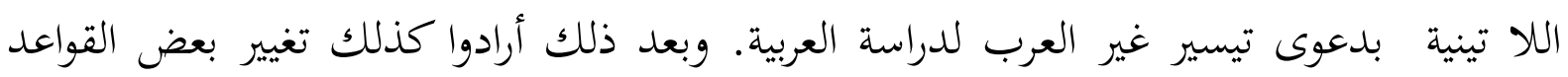

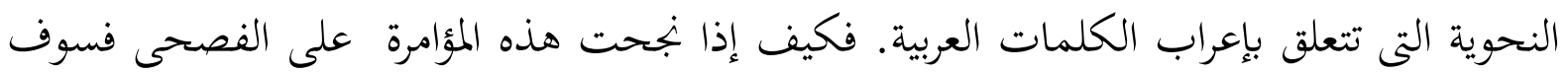

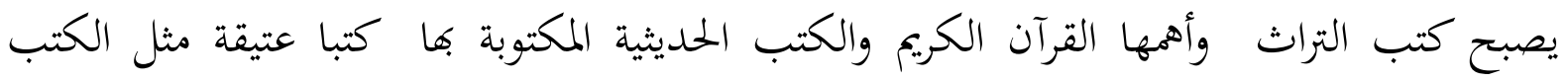
السنسيكرتية عند الهنود ولا يستطيع قراءها وفهمها إلا المتخصصون مع صعوبة كثيرة لفك رموزها.

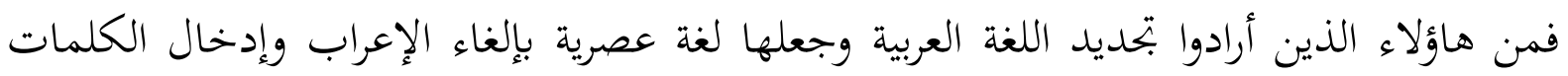

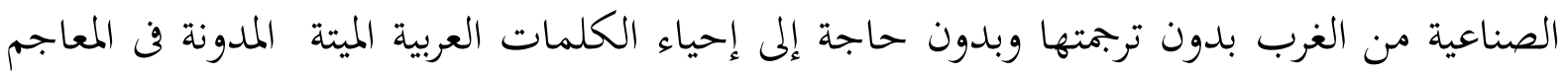

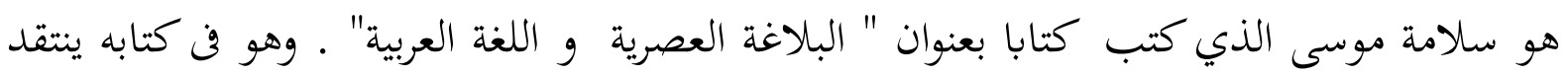
نقدا شديدا للمحافظين على فصاحة اللغة العربية كما هى واردة في الآداب العربية القديمة المشتملة

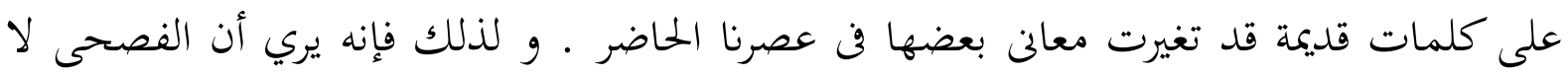

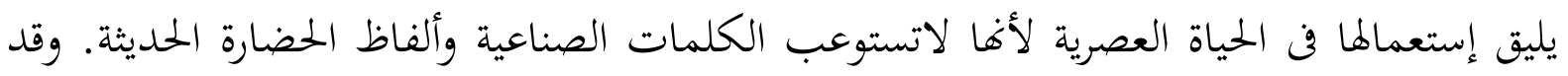

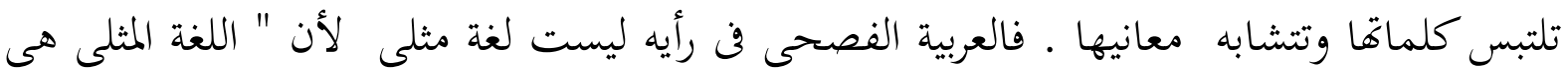

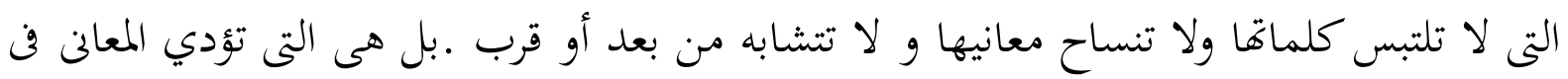

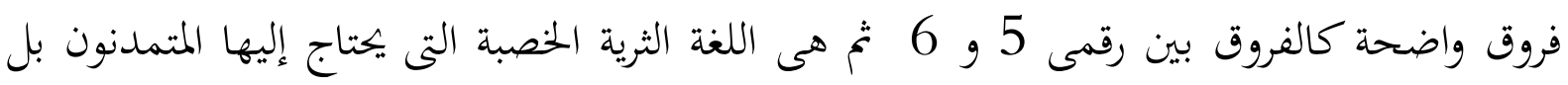


هى التى تتسع أيضا لإختراع الكلمات الجديدة التى تتطلبها الحاجات النامية المتزايدة لمئولاء

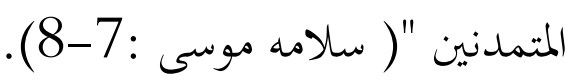

العربية لغة عالمية

بجانب مكانتها الممتازة وقداستها عند المسلمين كلغة القرآن الكريم, فإن العربية قد صارت لغة عالمية

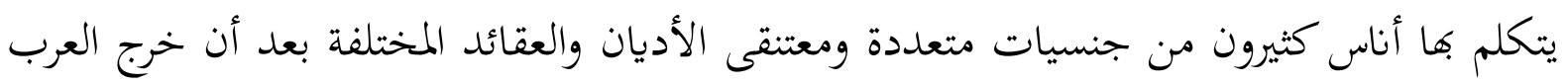

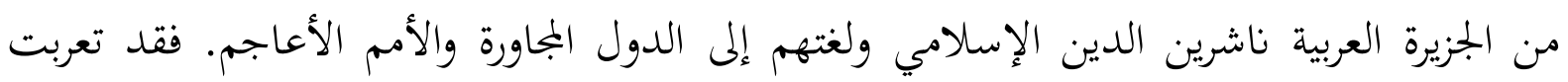

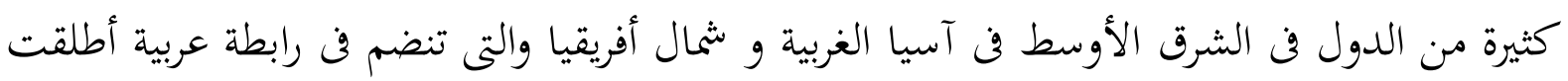

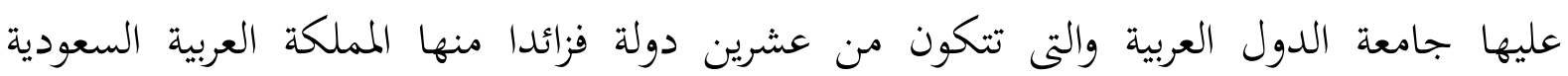
وجمهورية مصر العربية ودولة قطر, و الكويت , و الإمارات , والجزائر , و اليمن , والعراق, وليبيا, والسودان , وغيرها. ومع مرور السنين و تقدم الأزمنة و تطور العلوم و الثقافات فقد انتشرت العربية

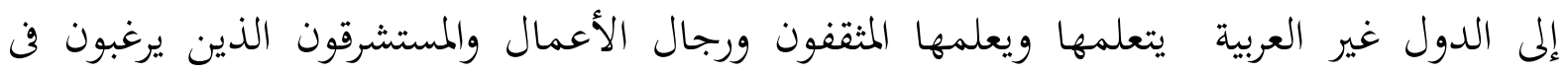

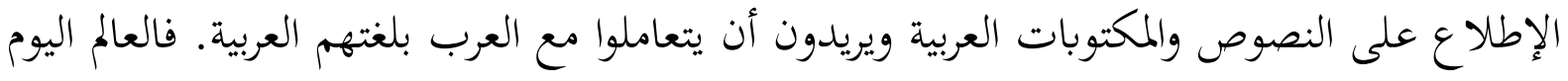

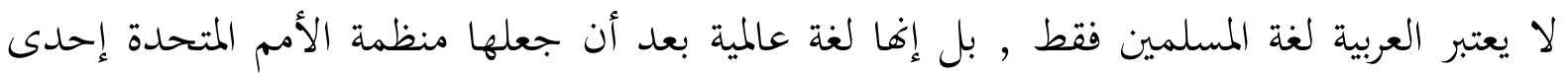
اللغات الرسمية فن إجتماعات جلساتا مع اللغات الرسمية الأخرى الإنجليزية والفرنسية و الصينية.

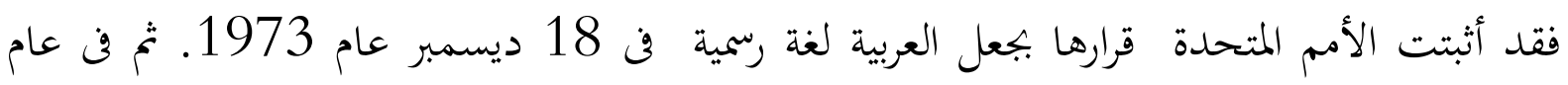

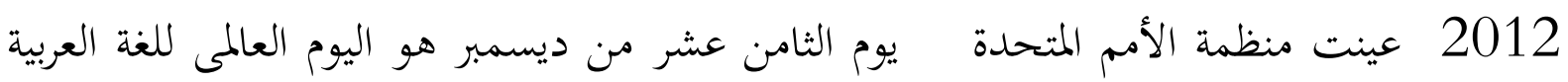

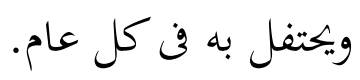

فاللغة العربية كلغة الدنيا أو اللغة العالمية لابد أن تساير ركب التقدم والتطورات فن مفرداتا و مصطلحاها فن علوم ومعارف شتى إجتماعية وسياسية و إقتصادية وثقافية.

ولكن هناك المشكلة أمام هذه الظواهراللغوية وهى أن العربية ليست كاللغات الأخري فن العالم لأهما

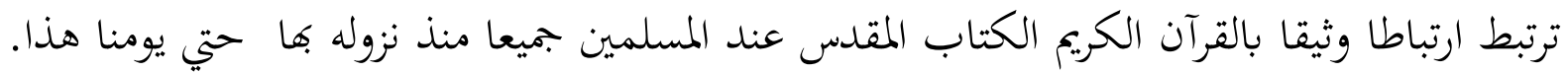

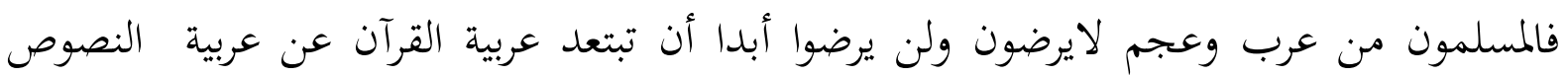

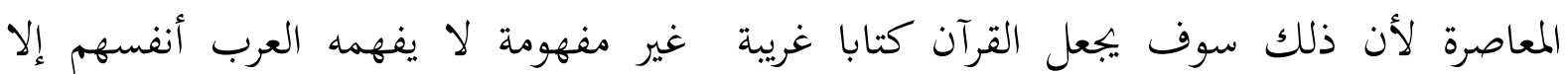


المتخصصون فن مطالعة النسخ العتيقة كالمصنفات الفلسفية اللاتينية عند الإغريق والكتب السنسيكرتية عند الهنود أو مثل القصص المكتوبة باللغة الإنجليزية القديمة فن زمن شكشبير وما قبله.

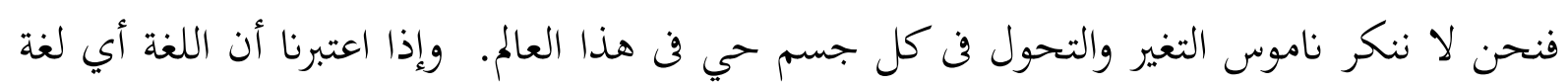

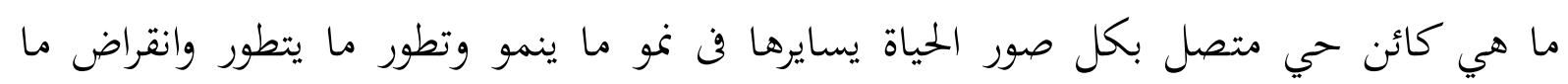
ينقرض فهي لذلك ليست ثابتة على حال واحدة بل هي خاضعة لناموس التغير والتحول. وقد صورإياس أنطون إلياس( 1988) هذا الناموس في العربية :

ويتمشى هذالناموس على لغتنا العربية تمشيه على غيرها من اللغات فقد كانت عند نشأهتا مؤلفة من

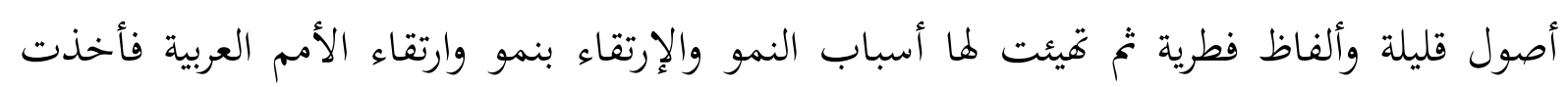
تكبر وتتسع دائرةا بالطرق الطبيعية التي ساعدت على نمو وارتقاء.

إن ما رآه إلياس أنطون إلياس من ضرورة تطوير اللغة العربية لمسايرة ركب الحضارة والتقدم نوافقه في

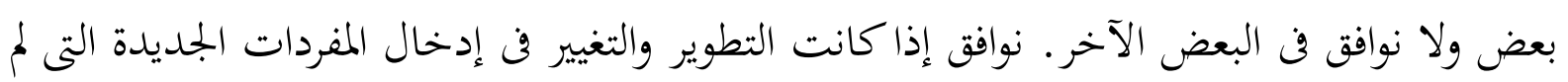

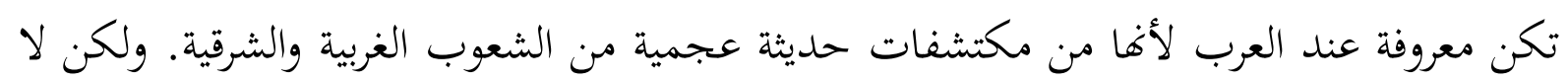

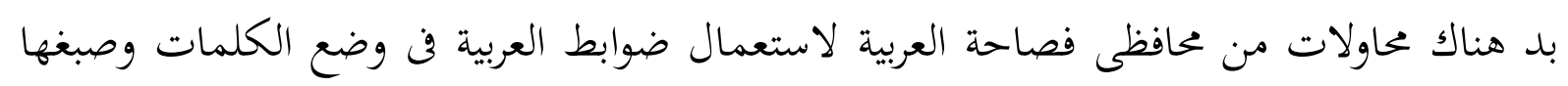
صبغة عربية عن طريق الإشتقاق والنحت والتعريب. فقد قامت المجامع اللغوية العربية بفعل هذا

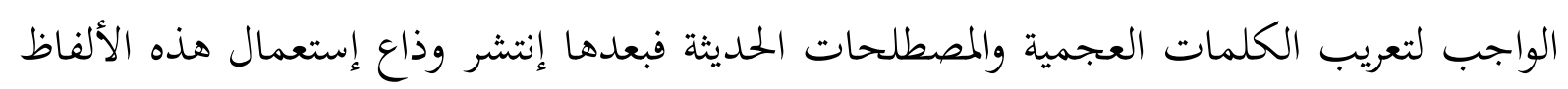

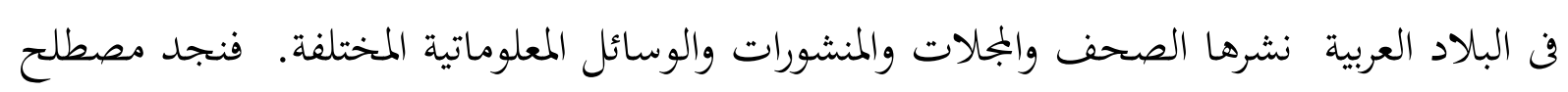

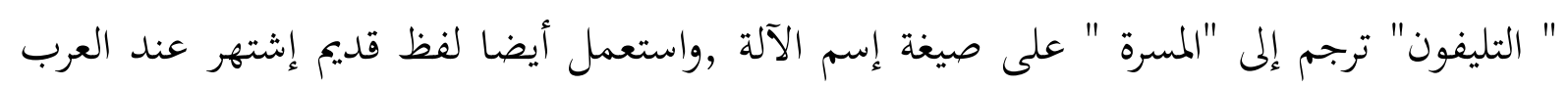

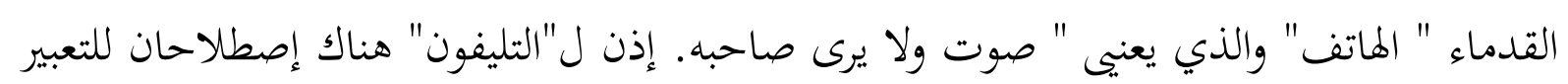

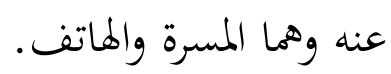

وكذلك المذياع = الراديو , مجهر = ميكروسكوب , بجهار = ميكروفون , برقية = تلغراف ,

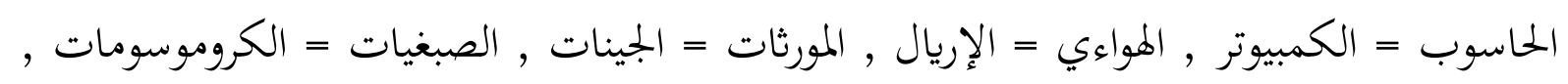
كهيرب = إلكترون الخ. 
وأما إذا نظرنا إلى النشاطات اللغوية في إندونيسيا كأكبر بلدان المسلمين في العالم بالنسبة إلى تعليم

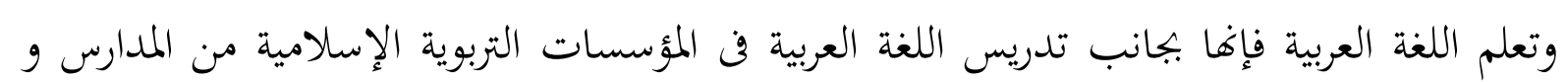

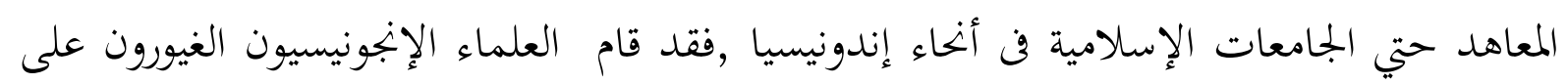
اللغة العربية بتأليف المعاجم والقواميس لمساعدة الطلبة الإندونيسين معرفة معانى المفردات العربية

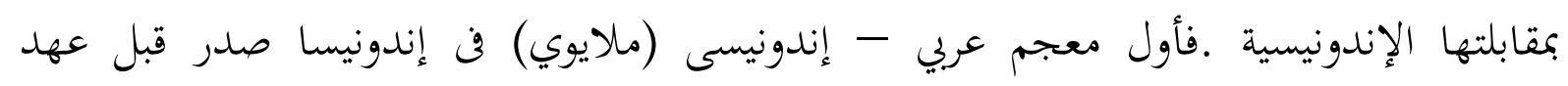

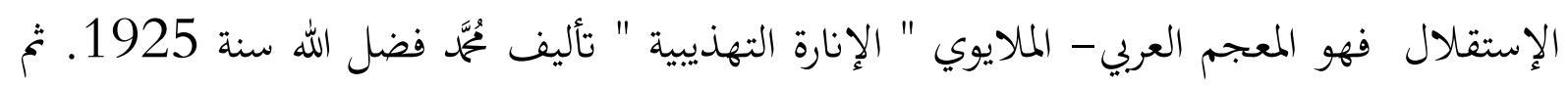

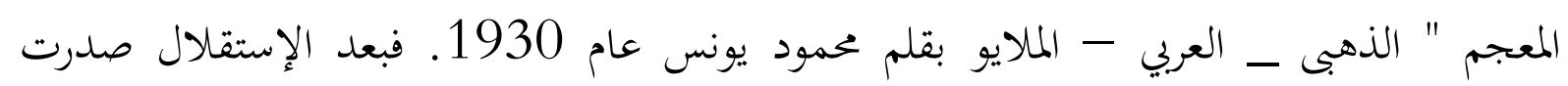

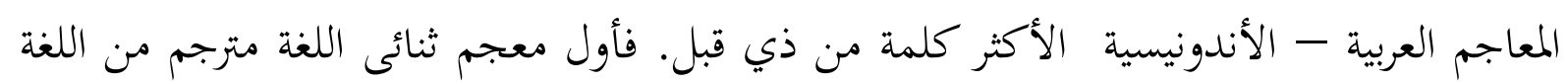

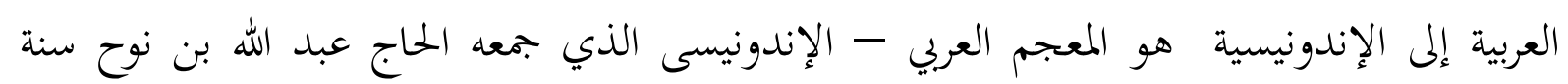

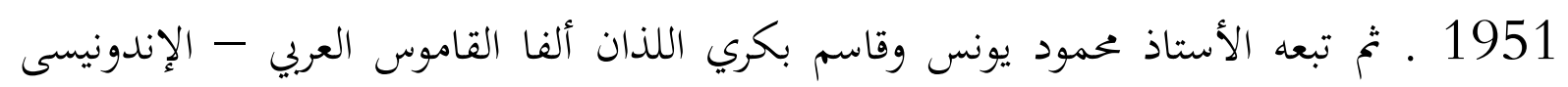

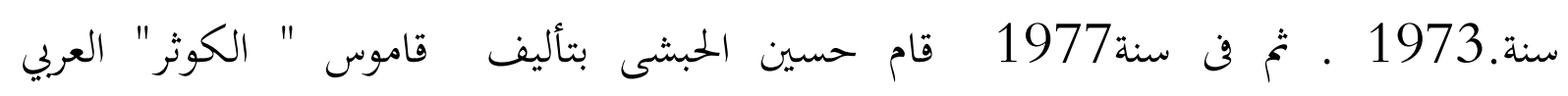
الإندونيسى. ففى سنة 1980 كتب حسن أحمد باهرون القاموس الموضوعى باسم بجموعات

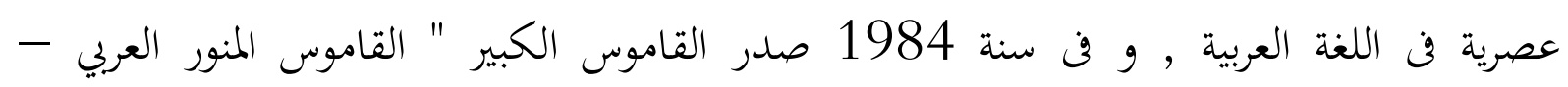

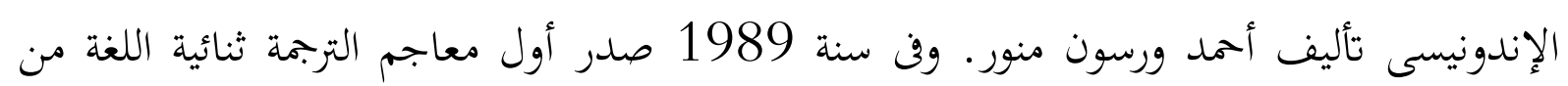

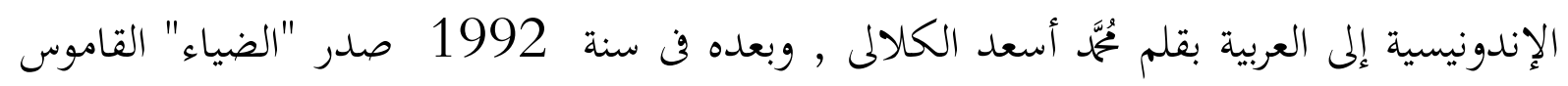

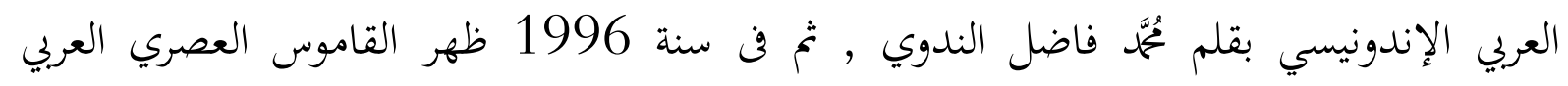
الإندونيسي بنظام جديد تحت تأليف أتابيك على وأحمد زهدي محضار, وبعده في سنة 1997

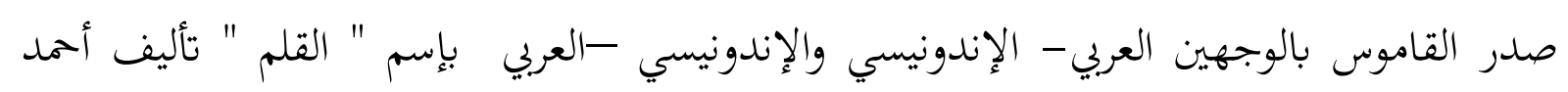

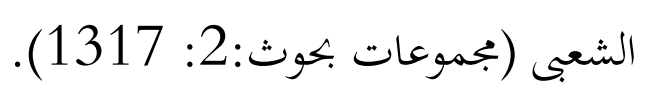

والمعجم العربي والقاموس العربي الأحادي و الثنائي اللغة لا أحد ينكر منافعها ومساعدةًا لطاب العربية لفهم النصوص العربية في الصحف والمجلات والمكتوبات العربية المختلفة.

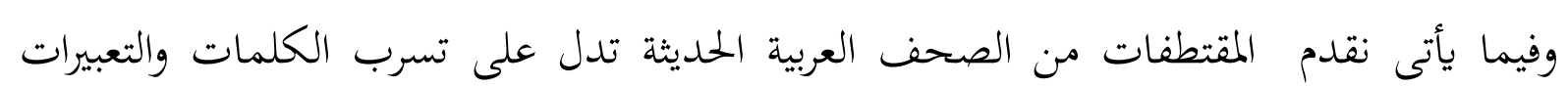
الحديثة : 
"سلطت قضية إعدام العالم النووي، \#شهرام_أميري ، الضوء على مسلسل إعدام وسجن وملاحقة

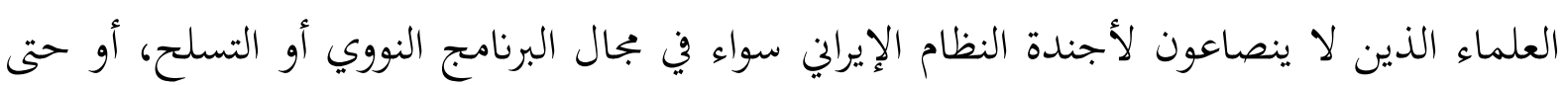
بما يتعلق برؤية النظام حول العلوم الإنسانية والاجتماعية والرؤى الفكرية والأيديولوجية كذلك.

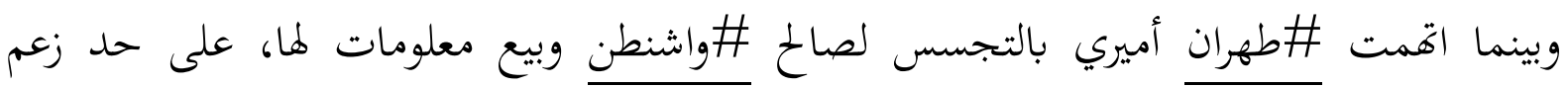

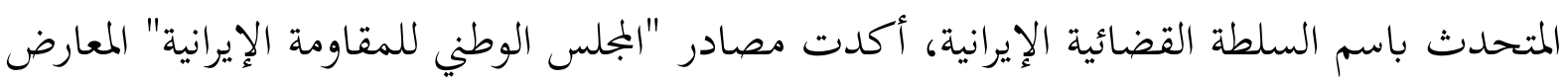

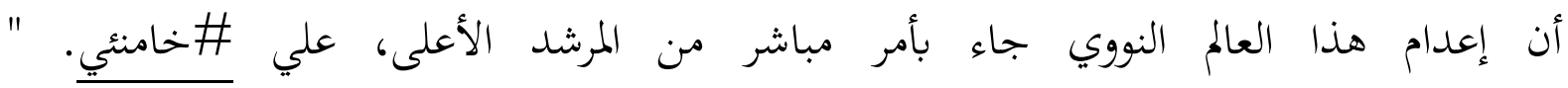

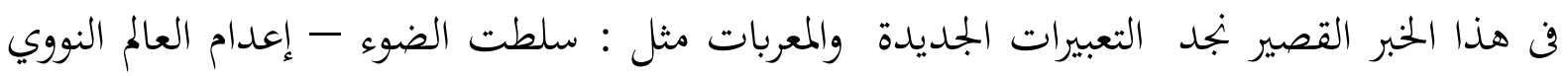
- أجندة النظام الإيرانى - رؤية النظام - الرؤي الفكرية و الإيديولوجية. وأسماء الأعلام : شهرام أميري - طهران - واشنطن- خامنئي. من العربية.نت. 22 ديسمبر 2017

"أثار مقترح قانون تقدّم به حزب العدالة التنمية الذي يقود الحكومة في \#ةالمغرب إلى البرلمان للنظر فيه، يدعو فيه إلى حماية وتنمية اللغة العربية وتطوير استعمالها في الحياة العامة وكل المجالات الثقافية

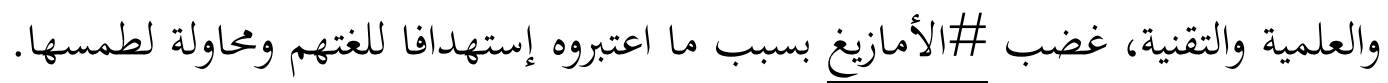

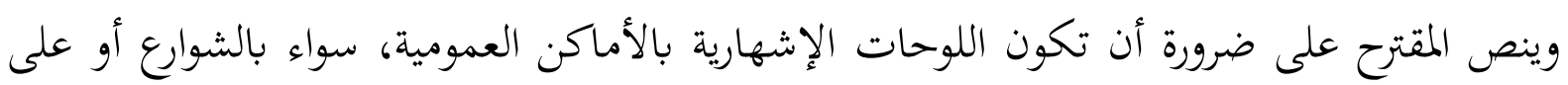

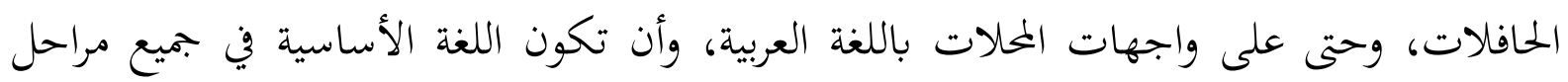
التعليم، سواء الابتدائي أو الثانوي وحتى الجامعي.

ووفيما يبدو أن الهدف من ذلك هو محاربة الاستخدام المفرط للغة الفرنسية في البلاد، فقد أثار مشروع هذا ل\#القانون غضب واستياء الحركة الأمازيغية، خاصة أنه يأتي في الوقت الذي لا تزال

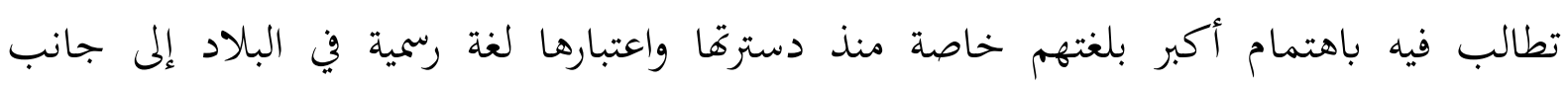

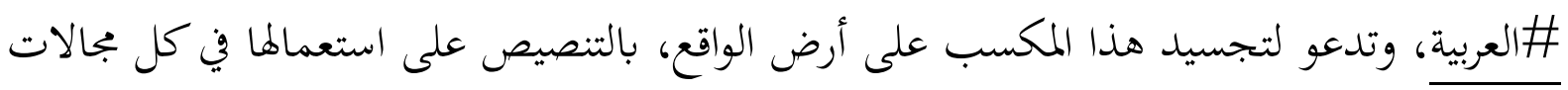
الحياة جنبا إلى جنب مع العربية." 
الإصطلاحات والتعبيرات الجديدة والكلمات الأعجمية في هذا النص منها : مقترح قانون البرلمان - التقنية - الأمازيغ - اللوحات الإشهارية - الحافلات - واجهات المحلات - منذ دسترتما ( مصدر مشتق من لفظ دستور )- تجسيد. من جريدة "الحياة" 31 أغسطس 2016.

" أوقفت السلطات التركية قائداً سابقاً للشرطة في مدينة اسطنبول، وحكّام مناطق وعشرة صحافيين، بينهم رئيس تحرير جريدة 》حرييت《 الناطقة بالإنكليزية، في إطار حملة لذانصفية) جماعة الداعية

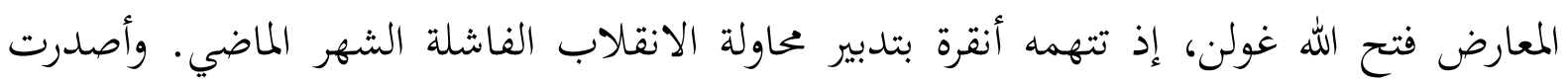
النيابة العامة في اسطنبول أمراً بتوقيف القائد السابق للشرطة في المدينة، حسين جابكابكين، وثلاثة إنة حكام، بعد ظهور 》أدلة جديدة) في تحقيق بتريه في الملف المالي لجماعة غولن.

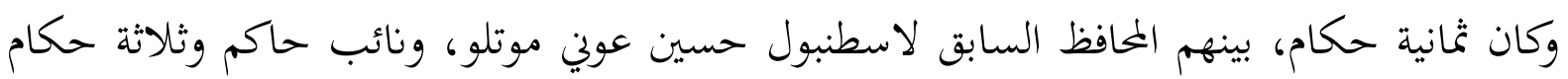
مناطق، أوقفوا هذا الشهر.

في غضون ذلك، أوقفت السلطات عشرة صحافيين أمس، في اسطنبول وأنقرة ومحافظة كوجالي شمال

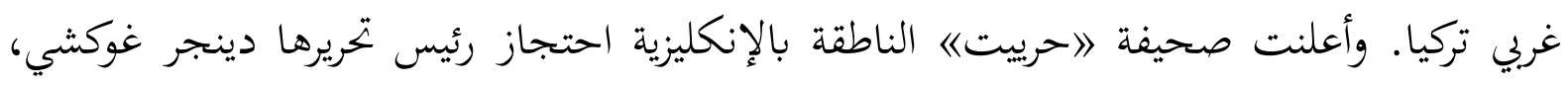

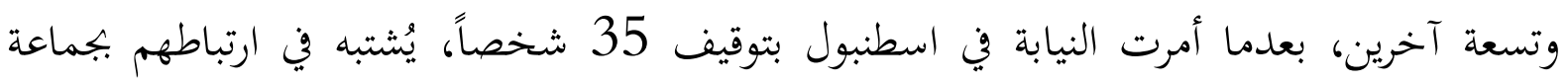

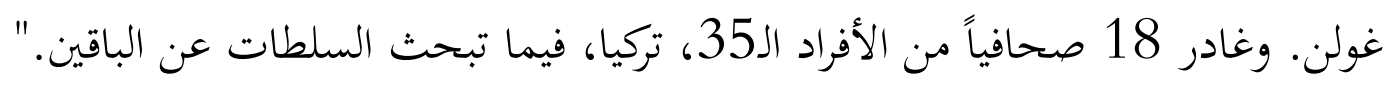

نجد فن الخبر التعبيرات الحديثة والأعجميات مثل : مدينة إسطنبول - حكام مناطق - رئيس تحرير -

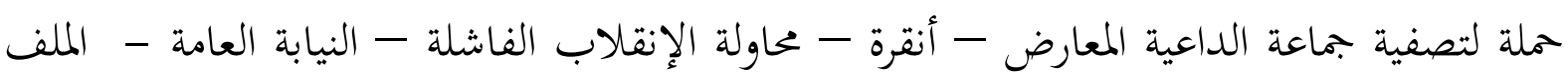
المالي - احتجاز - شخص يشتبه في إرتباطه.

$$
\text { من "العربية ـ نت. " } 8 \text { مارس } 2019
$$

"خلال القرن الماضي، شهد العالم ظهور العديد من الحركات المطالبة بالمساواة بين المرأة والرجل، وقد نشطت أغلبها في كل من الولايات المتحدة الأميركية وبريطانيا وفرنسا. 
واعتبر حق الاقتراع للمرأة أبرز ما طالبت به تلك المنظمات أو الحركات، حيث أكد كثيرون حينها

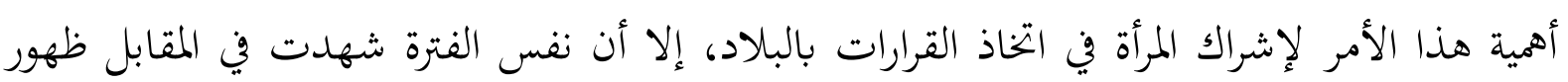
حركات أخرى عارضت بشدّة منح حق الانتخاب للمرأة.

وقد عرفت بريطانيا أهم تلك الحركات، إذ شهدت ظهور منظمة نسائية عرفت بالرابطة الوطنية

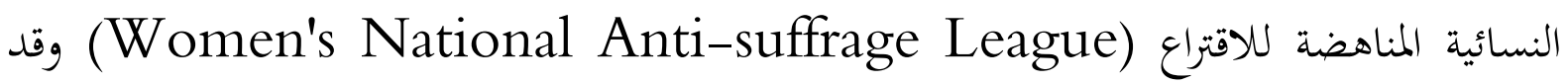
ضمت هذه المنظمة في صفوفها عددا هاما من النساء المرموقات في البلاد.

\section{أهم نساء بريطانيا}

ولعل أبرز الأسماء التي عارضت حصول المرأة على حق الاقتراع عالمة الآثار والمستكشفة والباحثة غيرترود بيل(Gertrude Bell) ، المولودة عام 1868، التي تصنف كواحدة من أهم النساء البريطانيات خلال القرن الماضي.

فقد حققت تلك المرأة إنجازا فريدا من نوعه، إذ أهت دراستها في بجال التاريخ المعاصر، وتخرجت من

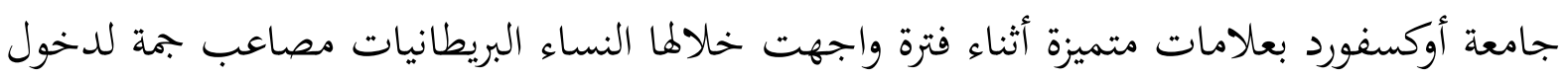
الجامعة ومواصلة تعليمهن.

إضافة لذلك، كان لغيترود بيل تأثير هام في بلاد فارس وبلاد الرافدين والجزيرة العربية، حيث سافرت وتنقلت بين مختلف تلك المناطق متحدّثة عنها وعن تضاريسها. شغلت منصب مستشارة المندوب السامي البريطاني بيرسي كوكس. (Percy Cox)

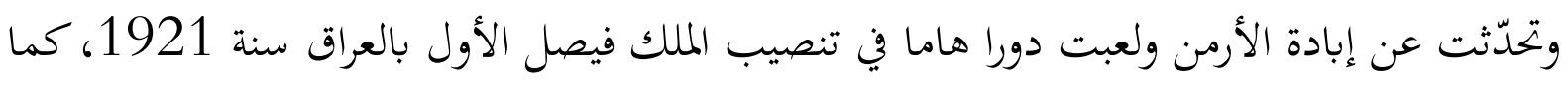
كان لها الدور الأهم في إنشاء المتحف الوطني العراقي.

وعلى الرغم من تلك المسيرة الحافلة والمشرفة لنساء بلادها في تلك الحقبة، إلا أن غيرترود بيل

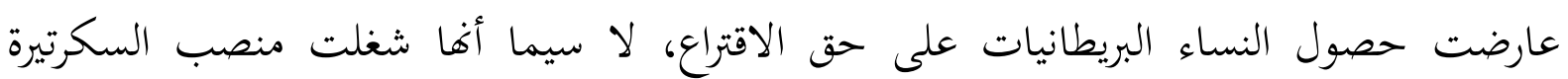

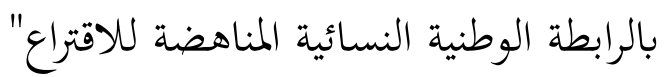


التعبيرات الحديثة و الكلمات الدخيلة : الحركات المطالبة بالمساواة بين المرأة والرجل - الولايات المتحدة الأمركية - بريطانيا - فرنسا- حق الإقتراع - حق الإنتخاب- الرابطة الوطنية النسائية المناهضة للإقتراع- عالمة الآثار والمكتشفة - جامعة أكسفورد - مستشارة المندوب السامى - إبادة الأرمن - السكرتيرة.

خاتمةت

إن اللغة العربية هى اللغة الوحيدة في العالم التى لما مكانة محتازة بكوها لغة الدين الإسالامى كلغة القرآن الكريم و الأحاديث النبوية وكتب التراث وكوها لغة العالم يستعملها أجناس مختلفة من معتنقى الأديان المختلفة في الدول العربية و غير العربية.

واللغة العربية تستطيع أن تحافظ على مفرداتها القديمة وقواعدها نهوها وصرفها وأساليبها وبلاغتها وحروفها الأبجدية وأصواتها بفضل نزول القرآن الكريم بها وجهود ومحافظة العلماء المسلمين البارزين من اللغويين والنحاة والمفسرين والمعجميين الذين قاموا ولايزالون يقومون بمواجهة وتفنيد المحاولات العدائية من المستشرقين و أذناهم لإزالة قواعد الإعراب و محو الحروف العربية واستبدالها بالحروف اللأتينية وترويج وتشجيع اللهجات السوقية الدارجة العامية في الأقطار العربية في إتصالهم بعضهم

بعضا.

إن ناموس التطور والنمو لا يجر على اللغة العربية بكاملها إلا فن كوها لغة عالمية بقبوها المفردات والمصطلحات الحديثة بعد تعريبها أو ترجتها ووضع الكلمات الجديدة عن طريق الإشتقاق والنحت وإخضاع الكلمات الأعجمية على متابعة طرق العرب فن النطق والكتابة.

\section{مراجع}

القران الكريم

أحمد بن الخشاب. مُحَّمّ عبد الله بن أحمد بن أحمد بن ، المرتجل في شرح الجمل، العام 492م .567 
أبو البقاء بن الحسين، العسكري، البلاغ في علل البناء والإعراب، تحقيق: غازي مختار طليان، (دار

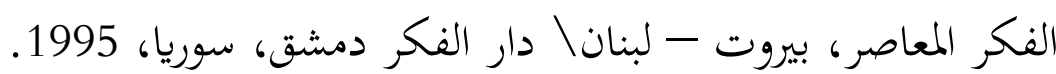

ابن عثمان بن قنبر. عمرو، سيبويه)، الكتاب، تحقيق : عبد السلام هارون، (دار الكتب، بيروت،

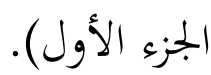

ابن يعيش النحوي. يعيش بن على، شرح المفصل، تحقي : جماعة من علماء الأزهر، (مطابع المنيرية، الجزء الثاني.

ابن فارس. أحمد، فقه اللغة العبية، تحقيق: أحمد بسج، (دار الكتب العلمية، بيرت، الطبعة الأولى، .1997

ابن عمر. عثمان، الكافية في النحو، شرحه: رضي الدين الاستراباذي، (دار الكتب العلمية، بيروت،

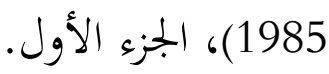

ابن عبد الله السهيلي. أبو القاسم عبد الرن، نتائج الفكر في النحو، ( الطبعة الأولى: بيروت -

$$
\text { لبنان)، العام. 1412هـ - 1992م. }
$$

ابن أحمد الفاكهي. عبد الله، شرحتاب الحلدود في النحو، (القاهرة: مكتبة وهبة)، العام. 1408هـ1988

الجبار. عبد، توامة التعدية والتضمين في الأفعال العربية، (دراسات في النحو العربي، ديوان المطبوعات الجامعية بن عكنون الجزائر، 1994.

حسين. ميوهوبي، معاني الحروف حروف الجر "أنموذجا،" مذاكرة لنيل شهادة الماستر في اللغة العربية وآدابها في تخصص علوم اللسان، (جامعة زيان عاشور الجلفة، 2017)،

الخطيب. طاهر يوسف، المعجم المفصل في الإعراب، (سنقافورة - جدة، اندونيسيا)، دون عام.

السيوطى. جلال الدين، الاقتراح في علم أصول النحو، (دار المعرفة الجامعية)، العام. 1426هـ 2006 
غلايين. مصطفى، جامع الدروس العربية،الجزء الثالث، (المكتبة العصرية: بيروت، الطبعة الثامنة

$$
\text { والعشرون)، العام. 1414هـ - 1993م. }
$$

فوال. عزيزه، المعجم المغصل في النحو العرب، (دار الكتب العلمية: بيروت - لبنان، الطبعة الأولى)،

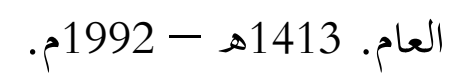

منظور. جمال الدين أبي الفضل تُحَّل بن مكرم، لسان العرب المجلد الثاني، (دار الكتب العلمية: بيروت

$$
\text { - لبنان، طبعة جديدة، الجلد: المادي عشر)، العام. 1430هـ - 2009م. }
$$

نموذجا. الغفران، استخدامات حروف الجر في التعبير الأدبي، (الرسالة المذكرة المقدمة لاستكمال سلامه موسى , البلاغة العصرية واللغة العربية , سلامه موسى للنشر والتوزيع , الطبعة

$$
\text { المزيدة } 1953 \text { و } 1964 .
$$

عبد الرحمن بن إبرهيم الفوزان , العربية بين يليك , كتاب الطالب , مكتبة الملك فهد بن عبد العزيز

$$
\text { , الرياض }
$$

عبد الغفور محمود مصطفى جعفر , التغسير و المفسرون في ثوبه الجلديل و دار السلام, القاهرة , .2007

إلياس أنطون إلياس وإدوار أ إلياس , قاموس إلياس العصري عربى- إنجليزي, شركة دار إلياس العصرية .

عزالدين عُحَّم نجيب , أسس الترجمة من الإنجليزية إلى العربية و بالعكس , مكتبة إبن سينا , القاهرة , .2005

عبد الغفار حامد هلال , العببية خصائصها وسماتها , مكتبة وهبه , القاهرة, 2004. أحمد بن فارس بن زكريا, دعجم المقاييس فى اللغة, حققه شهاب الدين أبو عمرو , دار الفكر, 1994 
اللغة العربية كونها لغة الإسلام و لغغة العالم

كتاب المؤتمر , الملتقى العلمي العالمي العاشر للغة العربية , اللغة والثقافة العربية في الجامعات والمدارس عبر القارات الخمس , جامعة بونتيانا لك الإسالامية الحكومية بالتعاون مع إتحاد مدرسي اللغة العربية بإندونيسيا 26-28 أغسكس 2016.

بحموعة بحوث اللغة العبية أساس الثقافة الإنسانية ,ج 1-2, الملتقى العلمي العالمي التاسع للغة العربية , جامعة مولانا مالك إبراهيم الإسلامية الحكومية مالانق و إتحاد مدرسى اللغة العربية

بإندونيسيا , 29-29 أغسطس 2015. 